\title{
Intersections
}

Canadian Journal of Music

Revue canadienne de musique

\section{John Beckwith and Brian Cherney, eds. John Weinzweig: Essays on His Life and Music. Waterloo: Wilfrid Laurier University Press, 2011. xiii, 402 pp., compact disc. ISBN 978-55458-256-3 (hardcover), ISBN 978-1-55458-321-8 (electronic format)}

\section{T. Patrick Carrabré}

Volume 30, numéro 2, 2010

URI : https://id.erudit.org/iderudit/1006381ar

DOI : https://doi.org/10.7202/1006381ar

Aller au sommaire du numéro

Éditeur(s)

Canadian University Music Society / Société de musique des universités canadiennes

ISSN

1911-0146 (imprimé)

1918-512X (numérique)

Découvrir la revue

Citer ce compte rendu

Carrabré, T. P. (2010). Compte rendu de [John Beckwith and Brian Cherney, eds. John Weinzweig: Essays on His Life and Music. Waterloo: Wilfrid Laurier University Press, 2011. xiii, 402 pp., compact disc. ISBN 978-55458-256-3

(hardcover), ISBN 978-1-55458-321-8 (electronic format)]. Intersections, 30(2),

117-119. https://doi.org/10.7202/1006381ar

All Rights Reserved (C) Canadian University Music Society / Société de musique des universités canadiennes, 2011
Intersections

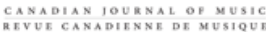

Ce document est protégé par la loi sur le droit d'auteur. L'utilisation des services d'Érudit (y compris la reproduction) est assujettie à sa politique d'utilisation que vous pouvez consulter en ligne.

https://apropos.erudit.org/fr/usagers/politique-dutilisation/ 


\section{BOOK REVIEWS / RECENSIONS}

John Beckwith and Brian Cherney, eds. John Weinzweig: Essays on His Life and Music. Waterloo: Wilfrid Laurier University Press, 2011. xiii, 402 pp., compact disc. ISBN 978-55458-256-3 (hardcover), ISBN 978-1-55458-321-8 (electronic format).

In 1982 John Weinzweig proclaimed, "The only work that has achieved the status of Canadian repertoire is the CBC One O'Clock National Research Council Time Signal" (275). Unfortunately, the situation has changed very little in the intervening years-except that fewer people now depend on the CBC for their music. While our national consciousness may resonate with the rugged landscapes of Emily Carr and the Group of Seven or the uncomfortable clashes of culture and status found in the fiction of Mordecai Richler and Margaret Laurence, it remains resistant to the modernist sounds of contemporary classical composition. Yes, there are now more Canadian composers than ever and they are regularly commissioned and performed across the country and abroad, but the ideal of a repertoire of Canadian concert music continues to evade us. Whether that is a good or bad thing is beyond the scope of this review, but there is no denying that John Weinzweig was a major force in the push to keep those sounds in front of as many people as possible in Canada, particularly after 1945, but right up into the new millennium. As composer, teacher, and lobbyist, he produced music, nurtured several generations of composers, and challenged the administrative and political establishment to do better for creative musicians.

This collection of broad-ranging essays evolved from a series of conversations between John Beckwith and Brian Cherney, the two editors, who are primarily composers ${ }^{1}$ and did not feel they could undertake a significant new study of his music on their own. So they decided to gather a collection of collaborators from different generations and backgrounds (composers, theorists, musicologists, and performers). With the Weinzweig centenary coming up in 2013, the time does seem right to encourage more discussion concerning his influence and, hopefully, performances of his music. This new volume makes a valuable contribution to the rather small body of research devoted to Canadian composers. ${ }^{2}$ It is divided into three sections, with the opening covering biographical themes, the larger middle segment dealing with aspects of

1 Although they have each made significant scholarly contributions: see especially John Beckwith, Music Papers: Articles and Talks by a Canadian Composer, 1961-1994 (Ottawa: Golden Dog Press, 1997), and Brian Cherney, Harry Somers (Toronto: University of Toronto Press, 1975).

2 Gail Dixon's book-length study The Music of Harry Freedman (Toronto: University of Toronto Press, 2004) brought the list of monographs on Canadian composers to eleven! 
his compositional technique, and a concluding portion under the title "The Legacy."

As research on Canadian composers goes, Weinzweig is already reasonably well represented by Elaine Keillor's John Weinzweig and His Music: The Radical Romantic of Canada (1994), which is only missing information on a handful of his late works. But in bringing together such a diverse group of authors, the editors have opened up the consideration of Weinzweig's music and his influence to a number of different analytical and critical approaches-some of which lead to refreshing results. The downside is that the volume reads like many Festschriften, lacking a coherent voice. The editors describe this as being "a serious study of various facets of John Weinzweig's life and work, without such technical complexity as would deter a general musical readership" (xi). While this is true for the most part, it is not a book to be read from cover to cover. A couple of the chapters speak primarily to context, where the composer makes only a cameo appearance (Robin Elliott's "Toronto: The Social and Artistic Context" and Stubley's "Ear-Dreaming: A Study in Listeners"), while others are decidedly personal (John Rea's survey of Weinzweig's students scratches some interesting scabs and Gillmor's "In His Own Words" (chapter 11) quotes some of the more scathing letters of reference, where I can often hear "John's" voice as if he were across the table at a meeting of the board of the Canadian League of Composers (CLC). 3

As a composer from a much younger generation, I came into contact with at least three very different John Weinzweigs, who might be labelled "the selfmade composer," "the activist," and "the first Canadian serialist," to use terms from the current study. As a dominant figure in organizations such as the CLC and the Canadian Music Centre (CMC), Weinzweig sometimes took on the role of gatekeeper-his strong opinion often defining what constituted "new music" in Canada. Alan Gillmor's discussion of the letters and writings gives a clear picture of Weinzweig's aesthetic boundaries, which did not encompass minimalism, neo-romanticism, or postmodernism (which he referred to as a "virus," 276). It is ironic that just as a young Weinzweig chafed against the "Edwardian time warp" (Gillmor's term, 270) that typified "English" Canada during his formative years, a subsequent generation of Canadian composers had to seek their own way around the modernist gatekeeper. ${ }^{4}$ John Rea's "The Teacher" (chapter 4) offers a number of examples from students of a later generation who were told, "We don't do that anymore" (90). As Alan Gillmor notes "There is something disingenuous about his rejection of other forms of modernism to the point of even suggesting that there should be some kind of a moratorium on the production of young composers" (276).

Weinzweig "the activist" comes clearly into focus in the chapters by both Gillmor and Cherney. While I was not convinced by the latter's search to

3 I sat as a CLC Board member from 1995 to 2005. John Weinzweig was president emeritus and an active participant in board meetings for most of those years.

4 The Minutes of the CLC do not reflect the reality that many new members were accepted while our distinguished president emeritus was on a bathroom break-for fear that he would attempt to "bar the gate" on stylistic grounds that had long been removed from the membership criteria. 
find the reason for Weinzweig's involvement in the political advocacy side of new music as some kind of parallel to his father's participation in the "Bund" movement in Poland, I could clearly hear John's voice again (for he would regularly read the CLC Board his latest scathing letter to a politician or CBC administrator).

Of the various Weinzweigs I came to know, it was "the self-made composer" whom I admired most and liked the best. Watching him rehearse with musicians and chatting with him at social functions introduced me to a creative mind that was still very much in love with making music. He had a wry sense of humour, so I appreciated Robert Aitken's use of his daughter's comments in his discussion of how to perform Weinzweig's music (chapter 14). She says, "Well, you'd better have a sense of humour ... If you didn't know him, it may be pretty hard to figure [out]. Because his humour is pretty dry" (349). A similar "dryness" seems entirely appropriate in the analytical chapters; Elaine Keillor's consideration of his radio and film music, Catherine Nolan's thoughtful study of his evolving serial technique, 5 Clark Ross's statistical analysis of his instrumental writing, Beckwith's consideration of his use of text as well as his use of "jazz" and "blues" elements, and James K. Wright's outstanding coverage of the Divertimento series. Each of the authors makes a worthwhile contribution to our understanding of how the craft of composition was practised by an important Canadian composer during one of the most tumultuous periods in musical history.

J. Drew Stephen and Eleanor V. Stubley each contribute chapters that deal with the reception of Weinzweig's work (the former in the scholarly community and the latter in the general listening community). Stephen does a good job of summarizing the existing studies, but Stubley goes somewhere unexpected. In trying to "ear-dream" how Weinzweig's music was received at five points spread over his career, she enters a world of speculation that has potential but at times seems a bit far-fetched.

An excellent sampler CD, including representative works covering Weinzweig's entire career, accompanies the volume. Put together by veteran CBC producer David Jaeger, it is one of the best parts of the whole project. As the disc played through, I was struck again and again by the quality of the music. A complete list of works and discography is also included.

Any composer who remains active for as long as John Weinzweig did is bound to go in and out of "fashion" during his lifetime. One who is as involved with the "political" side of things runs the risk of having his public feuds overshadow the importance of his music. This may have happened to this "selfmade composer." If such is the case, then I hope that time will give performers and listeners the distance necessary to hear his compositions with fresh ears. This volume should help.

T. PATrick CARrabré

5 She makes reference to the excellent article by Joseph N. Straus, "A Revisionist History of Twelve-Tone Serialism in American Music," Journal of the Society of American Music 2, no. 3 (2008): 355-95. 